\title{
Fantázia az oktatás gazdaságtanában
}

\author{
Horváth Szilárd ${ }^{1}$
}

\begin{abstract}
Fantasy in the Economics of Education. In the field of competences measured by PISA surveys, Hungarian students are lagging behind OECD countries. The recent reforms have not yet shown their expected impact. Professionals and laymen usually explain the disappointing results by the fact that education is an underfunded sector. The study depicts what would happen if we doubled the current amount so that the funding of Hungarian education could well exceed the OECD average. It is an eternal question whether all that count is money. Because in our imaginary scenario, in a short period of time modern, clean, new buildings would replace the old, sometimes musty school buildings; we would find the latest multicore computers instead of the $10+$ years old IT systems; and the traditional chalk boards would be replaced by interactive boards . The fact that there is a negative relationship between school computer usage and student performance improvements has already been demonstrated in the 2009 PISA study. However, the key to education is the pedagogue. Without training the right professionals, without their appreciation or motivation, the additional expenditures invested in education are meaningless.
\end{abstract}

Keywords Education finance, quality, luck, career model

\section{A magyar oktatás minősége nemzetközi összehas onlítás ban}

A lisszaboni stratégia célkitüzése, hogy az Európai Unió a világ legversenyképesebb térségévé váljon. Ennek a stratégiának egyik fó célja a tudásalapú társadalomés gazdaság megteremtése. Ennek ellenére a 2016. év végén napvilágot látott 2015-ös PISAfelmérés eredményei elkeserítő képet adtak hazánk közoktatásban nyújtott teljesítményéről. Holott a magyar közoktatás komplex reformja évek óta folyik hazánkban.

A 2015-ös PISA szövegértés feladatok alapján hazánk a 35 OECD állam rangsorában a 30. helyen szerepel. Hasonlóan gyenge eredményeket értek el a tanulók a matematika kompetencia területén is, ahol a 477 pont a 28 . hely megszerzéséhez volt ele-

${ }^{1}$ Kaposvári Egy etem, Gazdálkodás- és Szervezéstudományok Doktori Iskola Email: hszilard79@gmail.com 
gendő. Hasonlóan a matematikához természettudományi tudományterületen a 28. helyen végzett Magyarország (PISA 2015). A PISA-felméréseknél minden országból 150 iskolát, továbbá minden is kolából 35 tanulót válas ztanak ki. Ezzel összesen 5250 tanulót jelölnek ki a szervezők azzal a céllal, hogy ors zágonként minimum 4500 diák írja meg a teszteket. A 2009-es és a 2012-es felmérésekben 34 OECD-ország és 31 partnerország vett részt (Balázsi et al, 2013). A PISA-program három évenkénti ismétlődő periodikus vizsgálataira az Európai Unió ún. 2020-as fejlesztési időszakában az eddiginél újabb szerep is ruházódott: eredményei az uniós fejlesztési forrásokat igénybe vevő országok számára (Oktatás és képzés 2020) referenciaértékkel rendelkező kvantitatív eredménymutatóvá (indikátorrá) váltak (Fazekas 2014). Steklács (2006) definícióját ismerve, talán nem túlzás azt állítani, hogy a magyar közoktatás ontja az írástudatlan, funkcionális analfabéta diákokat. Steklács (i.m.) idézi az UNESCO 1999-es meghatározását, mely szerint ,[a]z a személy funkcionálisan írástudó, aki birtokában van mindannak a szükséges tudásnak és képességnek, amely képessé teszi ôt arra, hogy gyakorolhassa mindazokat a tevékenységeket, amelyekhez az írástudás szükséges ahhoz, hogy hatékonyan közremüködhessen az adott csoportban és közösségben, valamint az a személy, az olvasás-, írás-, és matematikai tudása lehetővé teszi, hogy használhassa ezeket a tevékenységeket a saját és közössége fejlődése érdekében."

A tanulói teljesítménymérések eredményei, mint a korábban ismertetett PISAeredmények, bár nagyon fontos aspektust vizsgálnak, nem feltétlenül adnak teljes és valós képet egy iskola pedagógiai munkájáról, annak minőségéről, eredményes ségéről. Sok esetben az adott évfolyamok összetétele, eltérö generációs adottságai, alapmotiváltsága is nagymértékben befolyásolhatják a tanulók teljesítményét. Nem beszélve arról, hogy az eredményesség nem kizárólag csak az oktatáshoz, hanem a neveléshez is köthetö, melynek mérése sok esetben nem, vagy csak közvetve, nehezen számszerüsíthetö. Mindez azt is jelenti, hogy nincs olyan egységes mutató, amellyel a diákok, pedagógusok és az iskolák eredményessége egzakt módon mérhető lenne, az egyszerü indikátorok mérésén túl a pedagógusmunka tényezőit a maguk komplexitásában érdemes vizsgálni (Sági 2006). Minden nemzetnek kiemelkedő célja kell, hogy legyen a megfelelő közoktatás megteremtése által a szükséges emberi erőforrás biztosítása. Az emberi erőforrás fejlettség egyik legmeghatározóbb tényezője az emberek iskolázottsága. A magyar népesség iskolázottsága a különbözö előreszámításokban egyáltalán nem kedvező. A magyar emberi erőforrás a fejlett világ fejlödési ütemétől elmaradó tempóban fejlődik. Különösen az utóbbi évtizedre (20052014) jellemző, hogy a korábbi felzárkózási trend helyébe, fokozatos lemaradás lépett a legfejlettebb országokhoz viszonyítva - állítja Polónyi (2016).

\section{A gyenge minőség egyik (lehetséges) magyarázata}

A laikusok többsége, de még az oktatásban dolgozó pedagógusok és szakemberek is azzal indokolják ezeket a jónak nem nevezhető eredményeket, hogy hazánkban a GDP százalékában kifejezett oktatásra fordított kiadás a térségben az egyik legalacsonyabb és az elmúlt években folyamatosan csökkent. A GDP arányában az egy tanulóra eső oktatási költségek viszont azt is jelzik, hogy az elvonások a közoktatás egyes elemeit nem egyformán sújtják. A közoktatási kiadások 2005-től fokozatosan visszaestek, így az egy diákra jutó kiadások is, míg az alapfokú képzésben a tanulólétszám drasztikus fogyásánál kisebb mertekben csökkentek a kiadások (Hermann, Varga 2011). Az elmúlt 
több mint egy évtizedben folyamatos forráskivonás jellemezte a magyar közoktatást. Amellett, hogy a normatív támogatás egységesülni láts zott az alap hozzájárulás szintjén, a különböző kiegészítő normatívák változása, illetve a normatív és a programfinanszírozás keveredése továbbra is megfigyelhetö. 2013-tól azonban az eddigi rendszert teljesen felülírta az iskolák államosítása (Szabó, Fehérvári 2013). A 2012-es PISA-jelentés szerint az OECD-országok egyértelmúen többet költenek az oktatásra mostanában, mint 10 évvel ezelött. A gazdagabb országok nyilvánvalóan többet, a szegényebbek pedig kevesebbet, és ez a különbség a teszteredményeken is meglátszott: azok az országok, amelyek többet költöttek az oktatásra, átlagosan 81 ponttal jobb eredményt értek el a PISA-teszten (OECD, PISA, 2012). Nem szabad figyelmen kívül hagyni azt a veszélyt, melyre Barber és Mourshed hívja fel a figyelmet, amely szerint az OECD szinte minden tagállama jelentős mértékben növelte oktatási kiadásait, és számos programot kezdeményezett a rendelkezés re álló összegek hatékonyabb elköltése érdekében. Ennek ellenére csak nagyon kevés ors zágnak sikerült az oktatási rendszer teljesítményében jelentős előrehaladást elérnie. Mintegy, országos értékeléseket és nemzetközi összehasonlításokat összegző tanulmány kimutatta, hogy számos ors zág es etében az oktatási rendszer teljesítménye egyáltalán nem javult, és volt olyan ország is, ahol egyenesen romlott (Barber, Mourshed, 2007: 10). Nem elfelejtendő az sem, hogy az oktatásban résztvevő egyénnek közvetlen és közvetett költségei is felmerülnek a képzéshez kapcsolódóan (Schultz 1983: 110). Egyéni közvetlen költségek: az egyénnek az oktatásban való részvétel miatt közvetlen fizetett pénzbeli kiadásai (tandijj, beiratkozási dijj, szállás-, utazási-, és ruházkodási költségek, iskolai felszerelések költségei). A kapott támogatások csökkentik az elöbbi költségeket. Egyéni közvetett költség: a képzésben való részvétel miatt elmulasztott jövedelem.

\section{Az oktatás gazdasági összefüggései}

A gazdasági fejlődés és az iskolázottság között elég egyértelmü együttmozgás van, ha a fejlett (OECD) országok egy före jutó GDP-je és az átlagos iskolázottságuk közötti összefüggést nézzük a korreláció 0,4115 (a 2011-es adatok alapján), ugyanakkor ezzel nem igazán tudunk sokat mondani a posztszocialista országok iskolázottsági jellemzőiről (Polónyi, 2013). Polónyi (2013) azt is állítja, hogy az oktatás és az egészség között más, ún. externális kapcsolatot is ismer a közgazdasági gondolkodás. Az externális vagy külső gazdasági kapcsolat - leegyszerúsítve - azt jelenti, hogy egy gazdasági tevékenységnek azok (a közösség) is élvezik hozamait, akik nem vesznek abban részt. Tehát az oktatás es etében maguk nem tanulnak, mégis has znuk van abból, hogy mások tanulnak. Az oktatás ilyen externális hozamai közé sorolják azt, hogy az iskolázottabb, tanultabb emberek egészségesebbek, s ezért kevesebb egészségügyi kiadást igényelnek, azaz a közösségnek kevesebbet kell az ő egészségügyi ellátásukra költeni. Hozzá kell tenni, hogy vannak olyan nézetek is, miszerint az iskolázottsággal részint növekszik a tájékozottság, s emiatt az emberek hamarabb fordulnak orvoshoz, részint a hosszabb élettartam miatt tovább is használják az egészségügyi szolgáltatásokat, s így végül is az egészségügyi kiadás nem is csökken, vagy nem csökken jelentősen.

A számítások azt mutatják, hogy ha a magyar közoktatás 20 év alatt eljutna arra a szintre, ahol ma a finn rendszer van, akkor a most született generáció életében nagyjából akkora megtérülésre számíthatunk, amekkora a magyar GDP hatszorosa. Képzeljük el, 
mennyi értéket állít elő Magyarország hat év alatt! Sok tízezer milliárd forintról van szó. Ennyi többletet jelentene a közoktatás megfelelö ütemü fejlesztése. Ez természetesen nem megy a közoktatási ráfordítások emelése nélkül. Kicsi a valószínűsége annak, hogy mi kevesebb pénzből kihoznánk ugyanazt az eredményt, mint amit Finnország produkál. De igaz ez megfordítva is: hiába költenénk el a közoktatásra ugyanazt az összeget, mint Finnország, ha azt nem legalább olyan okosan tesszük, mint ahogy Finnországban történik, a ráfordítások egy része kárba veszne. Ez a tényekre alapozott döntéshozatal jelentősége (Csapó 2011). Ezek ismeretében jól látható, hogy valóban nem elhanyagolható az az oktatáspolitikai kérdés, hogy mennyit költsünk a közoktatásra. Fontos kérdés, ahogy az egyén úgy a társadalom számára is.

\section{A többletforrás biztos megtérülés?}

2014-től némi növekedés figyelhető meg az oktatás finanszírozásában, KSH adatok alapján elérte a GDP 4,3\%-át. Ez a növekedés azonban koránt sem ad okot a megnyugvásra, hiszen az intézmények müködtetésének állami kézbevétele és a pedagógus életpályamodell bevezetése eleve jelentős többletforrásokat igényel. Ezek ismeretében ez az összeg már nem is olyan kecsegtető. De, játsszunk el a gondolattal, hogy ha ezt a GDP arányos költést megdupláznánk vagy akár megsokszoroznánk, egyenesen következne-e ebből a köznevelés minőségénekugrásszerü növekedése? Az oktatáskutatókazt állítják, hogy a megfelelő minőségű közoktatás müködtetéséhez a GDP nagyjából 6\% át kellene az oktatás finanszírozására költenünk. Ha csak megdupláznánk a GDP arányos oktatási költségeket, akkor az 1 . ábrán látható képet kapnánk:

\section{1. ábra. A GDP arányos finanszírozás duplájára növelése}

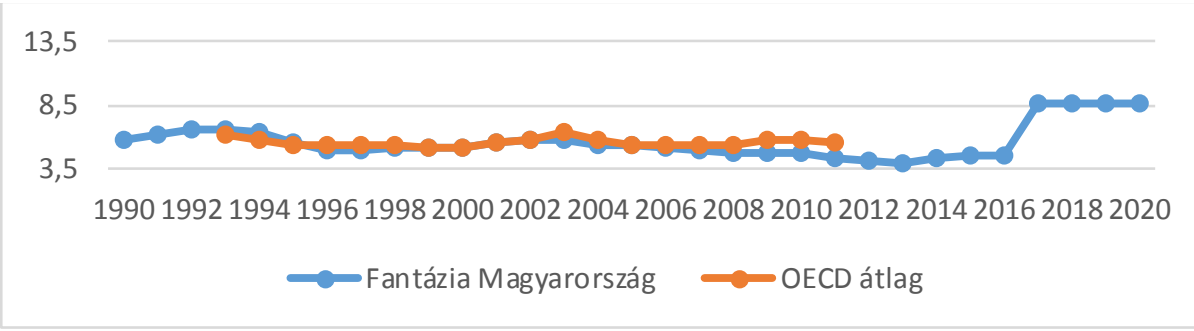

Az ábráról jól látszik, hogy magunk mögött hagynánk finanszírozás terén az OECD államokat, de javulna-e vajon ugrásszerüen a diákok teljesítménye csak azért, mert rövid időn belül az öreg, olykor dohos iskolaépületek helyére modern, tiszta új épületek épülnének; a sokszor több 10 éves informatikai rendszerek a legújabb sok magos számítógépek; a hagyományos krétás táblákat interaktív táblák váltanák fel; az intézmények új tornacsarnokokat, uszodákat kapnának? Feltételezhetően nem, de biztos an nem arányosan a kiadások növelésével.

Az, hogy az is kolai számítógép-használat és a tanulói teljesítmény javulása között negatív a kapcsolat, már a 2009-es PISA-vizsgálat is kimutatta. Az infokommunikációs eszközökbe invesztált erőforrások és a szövegértés, matematikai és természettudományos müveltség javulása között nincs kapcsolat, ezért minél több az egy tanulóra jutó 
számítógép és informatikai eszköz az iskolában, annál inkább romlott a matematikai teljesítmény 2003 és 2012 között (OECD 2015).

Az oktatási környezet technológiájának pedagógiai áttekintése is megmutatja, hogy a technológiai változás lehetőséget teremt a tanítási-tanulási folyamatról szóló gondolkodás megváltoztatására. Ehhez szükséges, de nem elégséges a technológia alkalmazásának pedagógiai szemlélete (Benedek 2013). Természetesen ez nem azt jelenti, hogy nem szükséges a megfelelő infrastruktúra biztosítása, de biztosra vehető, hogy önmagában nem elégséges.

\section{Az eredményesség növelésének elengedhetetlen eszköze}

Fantáziálhatunk kimagas ló oktatásfinanszírozáson, de sejthető, hogy ez az ugrásszerü növekedés nem következhetne be, mert mint tudjuk, a köznevelés egy hosszú távú komplex folyamat, melynek egyetlen indikátorának megváltoztatása nem jelenthet hosszú távú pozitív irányba történő elmozdulást. Ahogy Sági és Varga (2010) fogalmazott: a diákok iskolai teljesítményét az oktatáspolitika által is befolyásolható tényezők közül leginkább a pedagógusi munka minősége határozza meg. A tanulásitanítási környezet más ös szetevőinek - az oktatásra fordított összegek nagyságának, az osztálylétszámnak, a tárgyi felszereltség színvonalának - sokkal kisebb mértékben mutatható ki a tanulók eredményeire tett hatása. A második McKinsey-jelentés arra hívta fel a figyelmet, hogy az oktatási rendszer különböző fejlettségi fázisaiban más-más oktatáspolitikai intézkedések szolgálják leginkább a további fejlődés lehetőséget. E szerint abban a fejlettségi fázis ban, ahol most Magyarország áll, kiemelt figyelmet kell fordítani a pedagógus pálya, mint hivatás fejlesztésére és megerősítésére (Mourshed, Chijioke, Barber, 2010).

Ezek ismeretében egyetérthetünk Karolinyné-val (2010) aki így fogalmazott: a méltányos, fair viszonyok kialakítása jelenti a biztonságos és egészséges munkakörülmények megteremtését, az alkalmazottak elégedettségének folyamatos javítását.

A pedagógusképzés minőséget két fő tényező határozza meg. Egyrés zt függ attól, hogy mennyire motiváltak és tehetségesek a hallgatok, másrészt attól, hogy a pedagógusképző intézményekben mire, hogyan, milyen hatékonysággal képeznek. A sikeres és eredményes oktatási rendszerrel rendelkező országok már a képzésre történő jelentkezés kor szelektálnak. A cél az, hogy a pályára leginkább alkalmas, legjobb képességü és legerős ebben motivált diákok nyerjenek felvételt. Erre csak akkor van lehetőség, ha nem mutatkozik hiány az érdeklődő hallgatókból. A pedagógusképzésnek és -pályának tehát megfelelően vonzónak kell lennie ahhoz, hogy versenyezni tudjon más képzésekkel, pályákkal (Sági 2012).

A költségvetésböl jelentős összeget szántak, szánnak az életpályamodell bevezetésére és müködtetésére, melynek segítségével a dolgozók jövedelme szinte minden esetben jelentősen növekedett. Természetesen az életptálymodellt is ahány pedagógus, annyiféleképpen ítéli meg. Az életpálya-modell bevezetését követően a pedagógusok sokasága mozdult meg: új képzettségeket szerzett, valamelyest változtatott tevékenységének struktúráján, hangsúlyokat helyezett át - felkészítette magát a változásra, vagy már meg is tette az első lépéseket e felé. A pozitív beállítódásúak úgy látják, hogy az életpálya-modell lehetőséget nyújt számukra a szakmai előrehaladásra, szakmai támogatást, szakmai értékelést, visszajelzést, 
továbbképzési lehetőséget jelent, magasabb teljesítményre sarkall, a minőségi munka nagyobb anyagi elismerését eredményezi, és javítja a pedagóguspálya társadalmi megbecsülését. Minél fiatalabb valaki, annál valószínűbb, hogy pozitív az életpályamodellel kapcsolatos beállítódása. Ezen túlmenően, az óvodapedagógusok és a kollégiumi nevelőtanárok is nagy valószínüséggel e típusba tartoznak.

A negatív általános beállítódásúakra ezzel szemben az jellemző, hogy az életpályamodellt egyfajta külső nyomásként élik meg, ami egyben újabb munkaterheket is jelent, fokozott szakmai ellenőrzéssel, és magában rejti a könnyebb elbocsátás veszélyét is. E beállítódás gyenge összefüggést mutat az életkorral (a fiatal középkorúak inkább hajlamosak ide tatozni) és az általános iskolai tanítói vagy tanári feladatkörrel (Sági 2015). Fontos tehát a megfelelő motiváció, mely a pályán tartja a szakembereket, mely nem csak a béreken keresztül érhető el. Míg a legtöbb országban a tanárok magányos harcosként állnak szemben a munkájuk során felmerülő problémákkal, addig a legsikeresebb oktatási rendszerek némelyikében, például Japánban és Finnországban a tanárok között magas szintü az együttmüködés, közösen alakítják ki az óratervet, részt vesznek egymás óráin, megbeszélik és kielemzik a látottakat, ezáltal támogatják egymás fejlödését. Ezek a rendszerek olyan munkahelyi környezet megteremtésére törekednek, ahol a közös tervezés, a tanítási tevékenység értékelése és a kollégáktól érkező vis szajelzések természetes és mindennapos tevékenységek, melyek jelentős mértékben hozzájárulnak a tanárok folyamatos fejlődéséhez (McKinsey \& Company, 2007).

Rövid összefoglalásul, Kertesi (2008) szavaival egyetértve elmondhatjuk: Az állam feladata az oktatási rendszer megszervezése, müködtetése. Az oktatás eredményességét azonban nem a ráfordítások mértékén lehet lemérni. Az erőforrások mennyiségén túl az összetételük és megfelelö felhasználásuk is lényeges. Az erőforrásokat könnyű elpazarolni, rosszul felhas ználni. A helyes hatékonysági szemlélet azt írja elö, hogy az oktatási rendszer eredményeinek és a ráfordításainak az összhangját kell megteremteni.

\section{Felhasznált irodalom}

Balázsi Ildikó, Ostorics László, Szalay Balázs, Szepesi Ildikó, Vadász Csaba 2012. PISA 2012 Összefoglaló jelentés, (OH, Budapest) 2013. pp. 13-47.

Barber, Michael, Mourshed, Mona 2007. Mi áll a világ legsikeresebb iskolai rendszerei teljesitményének hátterében? McKinsey \& Company, Budapest, szeptember.

Benedek András 2013. Digitális pedagógus 2.0. Typotex Kiadó, Budapest

Csapó Benő 2011.A nemzetközi felmérések eredményei - következtetések a magyar közoktatás fejlesztésének megalapozásához, Szegedi Tudományegyetem Neveléstudományi Intézet,MTA Konferencia, Budapest, [http://www.ttudok.hu/?page=hu/konferencia/53-mit-mondanak-a-tenyek-az-uj-kozoktatasitorveny-kuszoben; utolsó hozzáférés: 2016.december 22.]

Fazekas Ágnes 2014. Az uniós oktatásfejlesztés új feltételei. Új Pedagógiai Szemle,No. 1-2. pp. $15-43$.

Hermann Zoltán, Varga Júlia 2011. A közoktatás finanszírozása. In: Jelentés a közoktatás ról 2010. OFI,Budapest.

Karoliny Mártonné, Poór József 2010. Emberi erőforrás menedzsment kézi-könyv. Rendszerek és alkalmazások. Budapest: Complex Kiadó Jogi és Üzleti Tartalomszolgáltató $\mathrm{Kft}$. 
Kertesi Gábor 2008. A közoktatási intézmények teljesítményének mérése-értékelése, az is kolák elszámolhatósága, in Zöld Könyv: A magyar közoktatás megújításáért, ECOSTAT, 2008, 167-171.

McKinsey \& Company 2007. Mi áll a világ sikeresebb iskolai rendszerei teljesitményének a hátterében? [http://www.onfejlesztoiskolak.hu/2008/mckinsey_magyar .pdf; utolsó hozzáférés: 2017. január. 15.]

Mourshed, Mona, Chijioke Chinezi, Barber Michael 2010. How the world's most improved schoolsystems keep getting better. McKinsey \& Company. [http://ssomckins ey.darbyfilms.com/reports/schools/How-the-Worlds-MostImproved-School-Systems-Keep-Getting-Better_Download-version_Final.pdf; utolsó hozzáférés: 2017. május 12.] [http://mckinseyonsociety.com/ downloads/reports/Education/Worlds_School_Systems_Final.pdf utolsó hozzáférés: 2017. május 12.] DOI: $10.17323 / 1814-9545-2011-\overline{2}-5-122$

Polónyi István 2013. Egészség, oktatás és emberi tőke. Educatio 2013/2 pp. 135-146.

OECD PISA 2015. Results in Focus [https://www.oecd.org/pisa/pisa-2015-results-infocus.pdf; utolsó hozzáférés : 2017. március 22.]

Polónyi István 2013. Iskolázottság, gazdasági fejlettség és kapitalizmusmodellek. Educatio 2013/4, 447-468.

Polónyi István 2016. A hazai emberi erőforrások ma és holnap, Educatio 2016/4, 481495.

OECD 2015. Students, Computers and Learning: Making the Connection, PISA, OECD Publishing. DOI: 10.1787/9789264239555-en

OECD PISA 2012. Results in Focus - What 15 year olds know and what they can do with what they know - OECD 2012. [http://www.oecd.org/pisa/keyfindings/pisa2012-results-overview.pdf; utolsó hozzáférés: 2016.október 06.]

Sági Matild 2006. A tanári munka értékelése és az iskolai eredményesség. In: Lannert Judit-Nagy Mária (szerk.): Eredményes iskola. Adatok és esetek. Budapest: Oktatáskutató Intézet, 111-128.

Sági Matild, Ercsei Kálmán 2012. A tanári munka minőségét befolyásoló tényezők, in Kocs is Mihály, Sági Matild (szerk.): Pedagógusok a Pályán, Budapest: OFI, 9-25.

Sági Matild, Varga Júlia 2010. Pedagógusok. In: Jelentés a magyar közoktatásról. [online] [http://www.ofi.hu/kiadvanyaink/jelentes-2010/18-pedagogusok; utolsó hozzáférés: 2016.06.10.]

Sági Matild 2015. Pedagógus karrierminták, Educatio, 2015/1. pp.83-97

Schultz, Theodore W. 1983. Beruházás az emberi tőkébe. Közgazdasági és Jogi Könyvkiadó, Budapest.

Steklács János 2006. Az olvasás jelentése és jelentősége ma. Csodaceruza, V. évfolyam 23.

Szabó Zoltán András, Fehérvári Anikó 2013. A közoktatás Fenntartói és finanszírozási változásai a jogszabályok tükrében (2010-2013) Új Pedagógiai Szemle 9-10: 5173.

A müre a Creative Commons 4.0 standard licenc alábbi típusa vonatkozik: $\underline{\text { CC-BY-NC-ND-4.0. }}$. 